\title{
Studies on Morphological Features and Biological Activities of the Genus Annona of Ethiopia, N. E. Africa with a Special Emphasis on Graviola: A Review
}

\author{
Harikrishna Ramaprasad Saripalli ${ }^{1}$, Prasanna Kumar Dixit ${ }^{2}$ \\ ${ }^{1}$ Research Scholar (D.Sc in Biotechnology), Berhampur University, Bhanja Bihar, Berhampur-760007 (Odisha), India. \\ Associate Professor, Department of Biotechnology, College of Natural and Computational Sciences, Aksum University, \\ Axum, Ethiopia P.O. Box: 1010, North East Africa. \\ ${ }^{2}$ Associate Professor, Department of Zoology, Berhampur University, Bhanja Bihar, Berhampur-760007 (Odisha), India.
}

\begin{abstract}
The Mother Nature provided us with a huge number of flora and fauna. These flora and fauna show so many characteristic features such as their medicinal value. Medicinal plants are the oldest known healthcare agents. Their importance is still growing although it varies depending on the phyletic, medical and historical background of each place. Medicinal plants are important for pharmacological research and drug development too, not only when plant constituents are used directly as remedial agents, but also when used as basic materials for the synthesis of drugs or as a models for pharmacologically active compounds. Some of the natural medicinal plants are very common, that we use in our daily life without knowing their medicinal importance. Worldwide, Annonaceae family is one of the large families showing many characteristic features such as antitumor, antioxidant, antimicrobial and many other bio-activities. The current review paper mainly focused on various biological activities of different species of the genus Annona of Ethiopia, North East Africa with a special emphasis on graviola.
\end{abstract}

Keywords: Annona, Graviola, biological activities, Ethiopia and North East Africa.

\section{Introduction}

The Annonaceae is a very large family of plants comprising about 120 genera and more than 2000 species. Basing on morphology and habitat, it is a very homogenous family producing edible fruits and oils. The Annonaceae family seems to be one of the minutest chemically as well as pharmacologically known families compared with its large size. The edible fruits and oils from seed of this plant have immense economic importance. Seed oils of certain Annonaceae plants are used in soap production and as edible oils. Flowers of some Annonaceae plants are used in perfumery and many members of this family are used in folk medicine to treat various types of tumors and cancers. The earlier studies on Annona species showed that this family is a potent source of a wide variety of secondary metabolites belonging to several categories (Pardhasaradhi, B.V et al., 2005). The most predominant species of the genus Annona includes Annona squamosa, Annona muricata L. (Graviola), Annona reticulata, Annona crassiflora, Annona cherimola, Annona glabra and Annona sylvatica. Whereas, in Ethiopia, North East Africa the commonly found Species of Annona are A. squamosa L., A. senegalensis Pers., A. reticulata L., A. cherimola Mill., and A. muricata. A. squamosa is a cultivated species of Annona which was collected deficiently. It ${ }^{\text {ee }}$ s quite possible that, $A$. muricata and $A$. glabra could also be grown in climatic conditions of Ethiopia. These species most frequently found being sold under the name of GISHTA (Amharic).

Annona L. In general

Trees, shrubs, subshrubs or small tree up to $1.5-10 \mathrm{~m}$ tall with mostly ovate or elliptic leaves and simple or stellate hairs or glabrous. Flowers usually hermaphrodite, solitary, fasciculate or in few-flowered cymes, terminal, leaf-opposed or extra-axillary, pedicellate; buds globose, ovoid or elongate, 3-angled; bracteoles 0-2, persistent. Sepals-3, valvate, free, smaller than the petals. Petals usually 6 in 1-2 whorls, both valvate or the inner one imbricate, subequal or the inner ones reduced or absent, free or united at the base, thick and leathery, mostly suberect or connivent. Stamens are numerous, linear or linear-clavate; filaments short; anthercells sometimes unequal; connective extension obliquely capitate, dilated or \pm apiculate. Carpels numerous, \pm united,cylindrical, with 1 erect basal ovule; styles clavate; stigmas rough. Fruit is pedicellate, syncarpous, fleshy, indehiscent, ovoid-globose or cylindrical. Fruits 6-25 cm long (cultivated or naturalized plants grown mostly for their edible fruits); Fruits $2.5-4.5 \mathrm{~cm}$ long (wild plants); Seeds are numerous, irregularly arranged; aril terminal, compressed, annular or grooved and ridged so as to appear as if made of fine thread-like fibres. Annona is a large genus of 110 species mostly available in tropical America, but a few species found in tropical Africa. Several species are widely cultivated for their edible fruits.

\section{Annona squamosa L.}

Annona squamosa L., known as custard apple, is often found in deciduous forests, also cultivated in wild in various countries. Literatures of many research works prove that every parts of $A$. squamosa possess medicinal property (Kirtikar and Basu, 1993). The species of Annona squamosa is a small evergreen tree reaching 6-8 meters (20-26 ft) tall; it is native of West Indies. It was a much branched shrub or small tree and grows up to 3-6m tall. Leaf blades are oblong, elliptic-oblong, oblong-lanceolate or narrowly elliptic, 7-17 x 


\section{International Journal of Science and Research (IJSR) \\ ISSN (Online): 2319-7064 \\ Index Copernicus Value (2013): 6.14 | Impact Factor (2014): 5.611}

3-5.5 cm, obtuse or sub acute at the apex, rounded or cuneate at the base, glabrous above, slightly pubescent or glabrescent beneath; petiole $0.4-1 \mathrm{~cm}$ long. Outer petals green, purple at the base, oblong, 16-25 x 6-7.5 mm, keeled inside; inner petals reduced to minute scales or absent. Fruits are globose or broadly conical, 5-10 cm long and wide, formed of loosely cohering or almost free carpels, the rounded ends projecting giving a tuberculate surface; surface greenish-yellow with a powdery bloom; pulp white tinged yellow, sweet. Seeds are shiny and dark brown in colour. Initially a native of the West Indies and South America, but now extensively cultivated throughout the tropics at low to medium altitudes; also naturalized near the coast in East Africa.

Annona squamosa is extensively used as traditional medicine in various cultures. The plant is traditionally used for treating epilepsy, dysentery, cardiac problem, worm infection, constipation, hemorrhage, antibacterial infection, dysuria, fever, and ulcer. It also possesses antifertility, antitumor and abortifacient properties (Asholkar, L.V et al., 1992). Roots are employed internally in depression of spirits and spinal diseases. Bark is known to be an awful astringent. In herbal medicine, fruits are considered as a good tonic, enrich blood, used as expectorant, hikes muscular strength, cooling, decreases burning sensation and tendency to biliousness, sedative to heart and alleviate vomiting (Patel and Kumar, 2008). The plant possesses potent bioactive ingredients in all of its parts. Acetogenins-a class of natural compounds, isolated from members of Annonaceae have potent antineoplastic, parasiticidal, pesticidal and anti-microbial activities (Oberlies, N.H et al., 1997). Acetogenins derived from long chain fatty acids are known to be powerful inhibitors of ubiquinone oxidoreductase in mammalian and insect mitochondrial electron transport systems (Degli, E.H et al., 1994). Two Acetogenins, squamocin and squamostatin are isolated from $A$. squamosa seeds have shown cytotoxic activity (Fujimoto, Y et al., 1994). Squamocin inhibited proliferation of HL-60 cells and induced apoptosis by the activation of caspase-3. Ascimicin, another acetogenin also exhibited cytotoxic activity against different tumour cells (Ruppercht, J.K et al., 1982). Squamocin-O1 and squamocin$\mathrm{O} 2$ were isolated from the methanolic extracts of the seeds of A.squamosa (Araya, $\mathrm{H}$ et al., 2002). Extracts of $A$. squamosa contains ribosome-inactivating protein (RIP), which acts as an immune-toxin is found to be effective (Sismindari et al., 1998). Leaf extracts of $A$. squamosa exhibited activity against different tested bacteria such as Bacillus megaterium, B. subtilis, Escherichia coli, Enterobacter faecalis, Proteus vulgaris, Pseudomonas aeruginosa and Staphylococus aureus. (Harikrishna Ramaprasad, 2004). Conventional aqueous extracts of leaves of Annona squamosa possessed antimicrobial activity against selected microbial strains such as B. megaterium, B. subtilis, E. coli, E. faecalis, $P$. vulgaris, $P$. aeruginosa, S. aureus, A. niger, A. fumigatus and $C$. albicans (Harikrishna Ramaprasad S, 2007 and 2012).

\section{Annona senegalensis Pers.}

A. senegalensis Pers (1806) is also called as A. senegalensis Roussillon (1969) or A. chrysophylla Boj. (1843) belongs to the family Annonaceae; other common/indigenous names are Af: Gishta, Am: Giishta, Yebere lib, Eng: Wild custard apple Or: Komate, and Wt: Eta. The species is widespread in tropical Africa, from Senegal to South Africa and Madagascar in semi-arid to subhumid regions. In Ethiopia, it is found in Combretum woodland and wooded grassland in the Moist and Wet Kolla agroclimatic zones of Wolega, Gojam, Ilubabor, Kefa, Gamo Gofa and Bale regions, 400 $1,600 \mathrm{~m}$. various parts of this plant possess several uses such as Firewood, timber, poles, tool handles, food (fruit), medicine (roots, gum, fruit), fodder (leaves, fruit), ornamental, windbreak, fibre (bark), yellow-brown dye (bark) (Edwards et al., 2000).

It is a shrub-like tree, $2-10 \mathrm{~m}$. Bark is grey and smooth, thick and folded when old, young stems hairy and orange red. Leaves are broadly oval, 15 x $10 \mathrm{~cm}$, blue green, hairy at the bottom, fragrant when crushed, on a short thick stalk. Shrub or small trees ranges (0.8-)1.5-10 m tall; bark is grey brown, often rough and corrugated; young stems are mostly redbrown velvety to greyish tomentose, at length glabrous; leaf bases and scars are mostly prominent, often with raised lines decurrent beneath them. Leaves are glabrescent or \pm hairy above, softly velvety tomentose beneath; consists outer 3 petals linear-oblong, inner scale-like. Fruits are edible appears as smooth to tuberculate. Leaf blades oblong to ovate or elliptic, (4-)6-18.5(-34) x 2.5-11.5 (-26) cm, obtuse or apiculate to rounded or slightly emarginate at the apex, cuneate or truncate to cordate at the base, papery to leathery, glabrous or sparsely pubescent above save for hairy midrib, glabrescent to thickly red-brown velvety beneath; petiole (0.5-)1-2(-2.5) cm long, glabrous to velvety tomentose.

Flowers are solitary or in bunches (fascicles) of 2-4, extraaxillary; pedicels $1-2.7 \mathrm{~cm}$ long, tomentose; bracteoles $1-2$ small or wanting; small flowers hanging down below twigs, yellowish with petals and sepals in threes; petals thick and hard, many stamens. Sepals are ovate-triangular, 3-4 x 4-5 $\mathrm{mm}$, obtuse to acute, pubescent or tomentose outside, glabrous inside. Petals greenish outside, cream or yellowish or pinkish within, sometimes blotched with purple, or crimson-blotched at base inside, fleshy; outer broadly ovate, 8-12(-15) x 9-11 mm, obtuse, adpressed grayish or yellowish pubescent outside, glabrous or minutely papillose within; inner narrowly oblong, 3-sided, 8-10 x 2.5-3 mm. Stamens are linear, 1.7-2.5 mm long; connective extension obliquely capitate, minutely papillose. Carpels are cylindric, 1-1.5 mm long and glabrescent.

Fruiting stalks 1.5-5 cm long; fruits yellow or orange, ovoid or globose, $2.5-5 \times 2.5-4 \mathrm{~cm}$; areoles slightly raised, very obtuse, glabrescent. Fruit is round, 2-7 cm, smooth, divisioned and pinkish green in color during un-ripened condition. When it turns into orange yellow and smelling like 


\section{International Journal of Science and Research (IJSR) \\ ISSN (Online): 2319-7064}

Index Copernicus Value (2013): 6.14 | Impact Factor (2014): 5.611

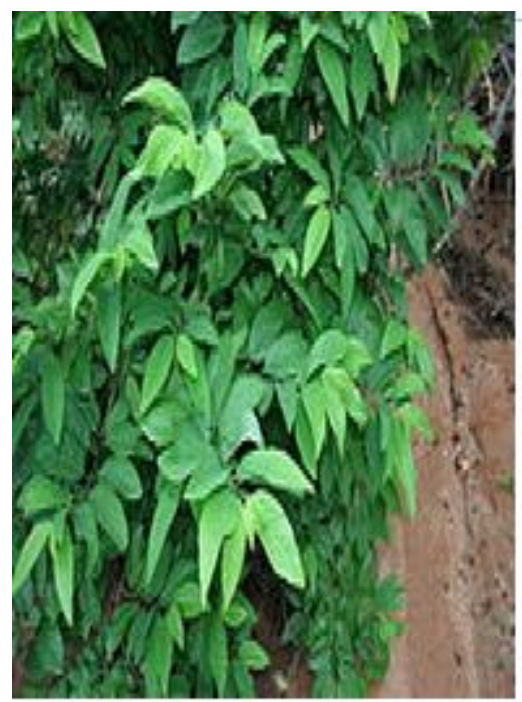

Shrub of Annona squamosa L.

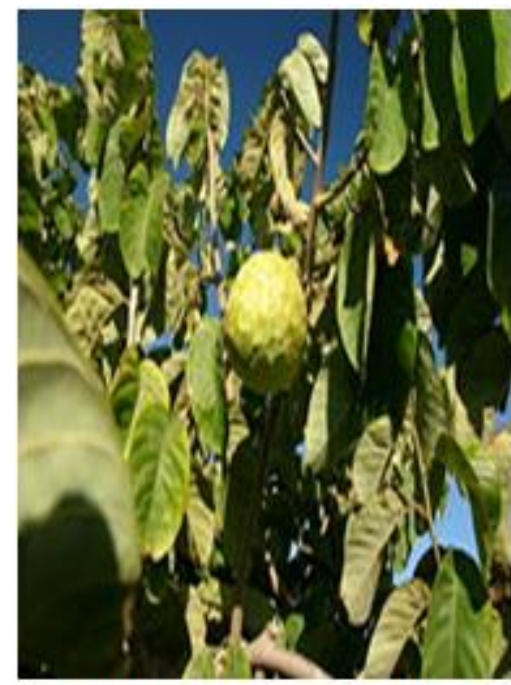

Fruit of Annona cherimola

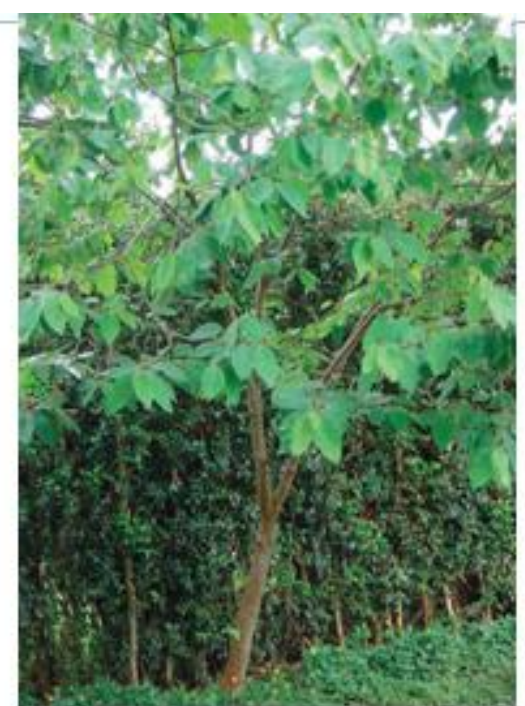

Tree of Annona senegalensis

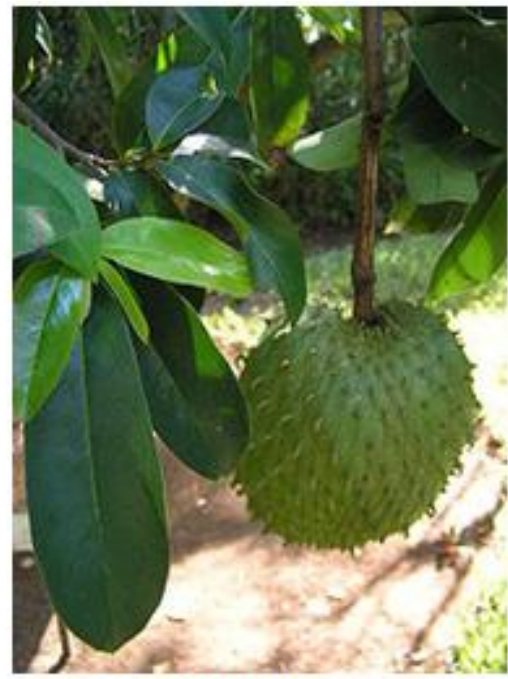

Fruit of Annona muricata

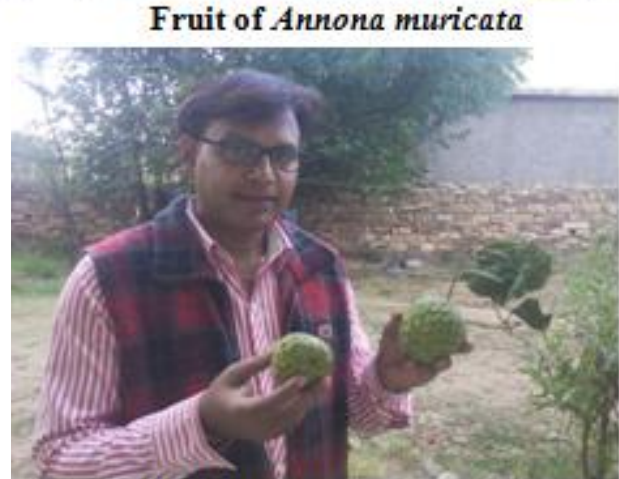

Fruits of Gishta (Annona senegalensis)

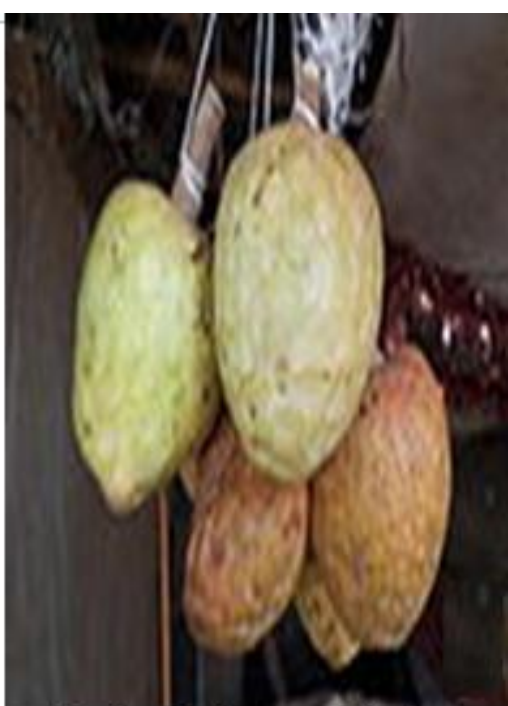

Fruits of Annona reticulate

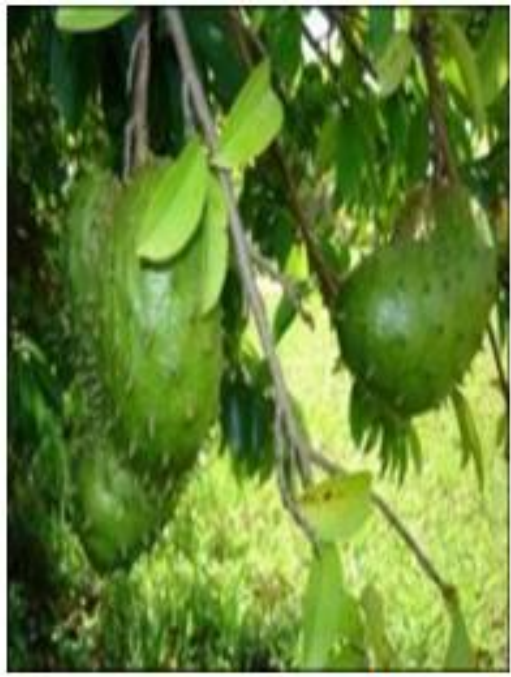

Fruit of Graviola

Figure 1: Fruits of different species of the Genus Annona

pineapple, the pulp is sweet and edible. Fruit covered with soft spines about $6 \mathrm{~mm}$ or so long or with conical protuberances or Fruit smooth or with areoles raised and rounded but without distinct spines.

Seeds are numerous in number and appear as orange-brown, cylindric, oblong, compressed, 8-14 x 4-6(-8.5) mm, 3.5-5 $\mathrm{mm}$ thick; aril of fine threadlike fibres, $\pm 2 \mathrm{~mm}$ long. Generally this plant is propagated in different ways like seedlings (sow seeds in pots), wildings, and root suckers from exposed or injured roots. The number of seeds per $\mathrm{kg}$ of fruits is about 2,500-4,000 depending on their size. Seeds are susceptible to insect damage and lose viability within 6 months. During storage of seeds add ash to reduce insect damage.

Traditionally, parts of this plant are used as medicines like, roots to treat cold; fruit against diarrhoea, dysentery and vomiting. Gum from the bark is used to seal small cuts and wounds, and even to plug leaking pots (Azene BekeleTesemma, 2007). 


\section{International Journal of Science and Research (IJSR) \\ ISSN (Online): 2319-7064 \\ Index Copernicus Value (2013): 6.14 | Impact Factor (2014): 5.611}

In general, A. senegalensis subsp. Senegalensis, the lower surface of adult leaves are sparsely to very densely pubescent with long hairs, but mostly red-brown velvety in those growing in eastern Africa. Usually they grow at wooded grassland on greyish clay, mostly in combretaceous woodland, ranges 500-1500m. Widespread in tropical Africa from Senegal to Cameroon, Zaire, Sudan and Kenya, extending to Zimbabwe and northern parts of South Africa; also in Madagascar, Comoros and Cape Verde; other subspecies extend to Angola.

\section{Annona reticulata $\mathrm{L}$.,}

Annona reticulata $\mathrm{L}$. is referred as bullock's heart, which is a slender semi-deciduous tree 6-7.5 m tall. Leaf-blades are oblong-lanceolate to lanceolate, $10-15 \mathrm{~cm}$ long, acute, glabrescent. Flowers are borne in small clusters on the new branchlets. Corolla white, the three outer petals linear oblong, $\pm 2.5 \mathrm{~cm}$ long, the inner small, ovate, scale-like. Fruit having a smooth skin that becomes dull red when ripe,

conical, ovoid or heart-shaped, up to $12.5 \mathrm{~cm}$ long, smoothsurface divided by impressed lines to form a reticulation, but areoles not much raised, loosely cohering fruiting carpels, which have markedly projecting rounded ends, so that fruit surface is covered with separate rounded lumps. These are cultivated and also persisting in abandoned gardens; originally from the West Indies (Edwards et al., 2000).

Annona reticulata L. Plant extracts consists a few volatile substances such as alkaloids, diterpenoids, and acetogenins (Ogunwande et al., 2006). Phytochemicals are secondary metabolic compounds found in plants. The important bioactive constituents of Annona reticulata are Alkaloids, Tannins, Flavonoids, Cardiac glycosides, Steroids and Saponins (Nithya, T.G et al., 2011). Solvent extracts of Annona reticulata showed antibacterial activity against gram positive and gram negative bacteria (Jansi Rani, D et al., 2013). The leaves are used as insecticides, anthelmintic, and are also used externally as suppurant. The bark is used as a powerful astringent, antidysentric and vermifuge. Root bark, leaves and stem possess isoquinoline alkaloids (Suresh, H.M et al., 2011). The ethanol extract of roots, shows antiproliferative activity of against cancer cell lines in vitro (Xu L et al., 1992).

\section{Annona cherimola Mill.}

A small deciduous tree with the lower surface of the leaves covered in a soft brown tomentum. Leaves \pm glabrous or subglabrous or sparsely hairy; outer 3 petals ovate, inner imbricate, somewhat smaller; fruit \pm smooth, edible with fleshy spines; areoles separated by a marked reticulation of, often raised, ridges but not themselves raised. Fruits are heart-shaped, roundish, green, 8-15 cm in diameter, with fingerprint depressions, with or without fleshy spines. Flesh is very sugary. These species are highly found in Ambo at around 2100-2200m. Native of Andean valleys in Ecuador and Peru, it can grow at higher altitudes than other cultivated Annona in the tropics (Edwards et al., 2000).

The plant contains biomolecules like carbohydrates, proteins (amino acids) and various secondary metabolites such as alkaloids, flavonoids, glycosides, saponins, tannins, phenolic compounds and phytosterols. The anti stress activity of cherimoya is mainly attributed to these constituents with established antioxidant activity (Adarsh Verma, $\mathrm{M}$ et al., 2011). The chemical composition of the essential oils of leaves, flowers and fruits of Annona cherimola were studied for its anti microbial activity (Maria Yolanda Rios et al., 2003; Rajiv Dahiya, 2007), anti viral activity (BetancurGalvis, L.A et al., 1999), cytotoxicity (Kim, D.H et al., 2001; Bode, A.M and Dong, Z., 2009; Newmann, D.J and Cragg, G.M. 2007).

\section{Annona muricata $\mathrm{L}$.}

A small, much branched, perennial tree, 3-8m tall, with terete having reddish-brown glabrous branchlets. Leaves are biseriate, shortly petiolate, pale green to bright green, oblong-obovate or oblongelliptic, $6-18 \mathrm{~cm}$ by $3-7 \mathrm{~cm}$ wide, glossy leaves and laurel-like with acuminate apex and cuneate or acute base. Flowers are regular, green to yellowish green (to yellow on a yellow fruited variety), on short axillary, 1-2 flowered branchlets. Flower has three dark green, ovate deltoid, coriaceous sepals which are pubescent and persistent; six broadly ovate, coriaceous, and usually green to subsequently yellowish-green, tomentose, cordate base petals; Petals all ovate, inner smaller but both whorls valvate; having numerous stamens in rows around the gynoecium; numerous ovary, pubescent with styles shaped like soft prickles. Fruit is oblong or somewhat curved, 15-35 $\mathrm{cm}$ by $10-15 \mathrm{~cm}$ wide, beset with soft spines with a thin, green or yellow or orange, inedible, areoles distinct, coriaceous rind. Seeds are numerous, obovoid and flattened, dark brown to black, glabrous and glossy, embedded in firm, white, fleshy, acid-sweet, juicy pulp(Edwards et al., 2000). It's a member of the family of Custard apple trees called Annonaceae. It is a typical tropical tree with heart shaped edible fruits and widely distributed in most of the tropical countries. Annona muricata produces fruits that are usually called soursop due to its slightly acidic taste when ripe. Trees grew natively in the Caribbean and Central America. It has been used in traditional medicine in many countries since long. Fruit extracts show antiviral, antinociceptive, antiinflammatory and antihyperglycemic properties. It is also effective against multidrug resistant cancer cell line (Nicholas H. Oberlies et al., 1997). The leaves are lanceolate with glossy and dark green in color had been traditionally used to treat headaches, hypertension, cough, asthma and used as antispasmodic, sedative and nervine for heart condition. Previous reports about this plant species from different countries have demonstrated that the leaf, bark, root, stem, and fruit seed extracts of Annona muricata are anti-bacterial. Annona muricata is a potent anticancer plant of Annonaceae family. Leaf extracts of A.muricata posses significant anticancer potentials in human cancerous cells. Plant phenolics are a major group of compounds that act as primary antioxidants or free radical scavengers (Polterait, O., 1997).

\section{Annona glabra}

Annona glabra (pond apple), is a tropical tree growing in wild in the countries like America and Asia. Petals are linear or oblong, the inner ones minute or scale-like. Leaves are velvety (Edwards et al., 2000). It is used in traditional medicine against several human ailments, including cancer. To validate the ethno pharmacological claims against cancer, 


\section{International Journal of Science and Research (IJSR) \\ ISSN (Online): 2319-7064 \\ Index Copernicus Value (2013): 6.14 | Impact Factor (2014): 5.611}

the anti cancer effects of alcoholic extracts prepared from pond apple leaves, pulp and seed, were investigated in human leukemia cell lines (Cochrane, C.B et al., 2008). Annona glabra has been reported to have a group of compounds called Acetogenins. Acetogenins are reported to possess potent cytotoxic activity and are potent inhibitors of mitochondrial complex I in respiratory chain (Gallardo, $\mathrm{T}$ et al., 1998). The leaves and bark of Annona glabra are used in Chinese medicine against cancer and other ailments. If the extracts of leaf, pulp and seed are compared, the seed extracts are found to be more potent than other extracts. Li et al isolated a cytotoxic cytopeptides from seeds (Li C.M et al., 1999). Cochrane et al has also reported the anti-cancer activity of Annona glabra extracts in human cancerous cell lines. On a preliminary screening, substantial antimicrobial, and cytotoxic activities were observed for the solvent extracts of the stem bark of Annona glabra (Padmaja, V et al., 1995).

\section{Graviola (Soursop)}

Graviola is a small, upright evergreen tree, 5-6m high, with large, glossy, dark green leaves. It produces a large, heartshaped, edible fruit that is $15-20 \mathrm{~cm}$ in diameter and green in color, with white flesh inside. The leaves, fruit, seeds, bark, root and stem are used to make varieties of medicines (Edwards et al., 2000).

Synonyms: Annona bonplandiana, A. cearensis, A. cherimola, A, macrocarpa, A. muricata, A.senegalensis, Brazilian cherimoya and Guanabanus muricatus (Edwards et al., 2000).

Graviola is a fruit that generally grows in the rain forests of Africa, South America, and Southeast Asia. It has also other local names like thorny custard apple, cherimoya and brazilian pawpaw. In various languages, this fruit is named differently like: Gishta (Ethiopia), guanabana (Spanish), corossol (French), aluguntugui (Ghana), sorsaka (Papiamento), adunu (Acholi), guyabano, guanavana, durian benggala, nangka blanda, sirsak, toge-banreisi, nangka londa, zuurzak, Brazilian Paw Paw, Corossol, Corossol Épineux, Corossolier, Durian Benggala, Guanabana, Guanavana, Nangka Blanda, Nangka Londa, Soursop, Sour Sop, TogeBanreisi. guanaba, épineux, huanaba, toge-banreisi, durian benggala and cachiman épineux. In India, it is less known as shul-ram-fal and hanuman fal, and as mullaatha in Malayalam, whereas in Harar (Ethiopia) in Harari language known for centuries as Amba Shoukh (Thorny Mango or Thorny Fruit). "yebere lib" meaning heart of cow in Jimma, Ethiopia (Blackherbals, 2012).

The bark, leaves, root and fruits of this tree are used for traditional remedies in many countries. Graviola extracts are used for treating virus or parasites infections, rheumatism, arthritis, diarrhea, dysentery, depression and sickness. Despite safety concerns, traditional medicinal practitioners claimed that graviola is used to treat infections caused by bacteria and parasites including leishmaniasis, a disease caused by parasites transmitted through the bite of sand fleas; herpes; coughs; and even cancer. It is also used to cause vomiting and to empty the bowels. Some people use graviola to help them relax. Graviola is applied to the skin in arthritis. As food, the graviola is mostly used in cooking and preparing beverages.

Many active compounds and chemicals have been found in graviola. Most of the research carried out on graviola in different countries focuses on a novel set of chemicals called Annonaceous acetogenins. Graviola produces these natural compounds in its leaf and stem, bark, fruit and seeds. These chemicals have significant antitumor properties and selective toxicity against various types of cancer cells (without harming healthy cells). Annonaceous acetogenins are only found in the Annonaceae family (to which graviola belongs). These chemicals in general have been documented with antitumorous, antiparasitic, insecticidal, and antimicrobial activities (Keinan, E., 1997-1998). These chemicals were less toxic; on considering the antitumor activity and its relative toxicity, they might be used as a lead to develop a potential anticancer agent (Wang, L. Q., 2002).

Graviola contains many chemicals that may be active against cancer (Nicholas H. Oberlies et al., 1997), as well as diseasecausing agents such as bacteria, viruses, and parasites. More evidence is needed to rate the effectiveness of graviola for their uses. There is a controversy regarding safety profiling of Graviola. It can kill nerve cells in the brain and other parts of the body. It may cause movement disorders. It is not advisable to use Graviola during pregnancy and breast feeding. Currently, there is no scientific information regarding the interactions of Graviola species found in Ethiopia and its appropriate dosage. Moreover, intense research works need to be undertaken on the Graviola species of Ethiopia, North East Africa to evaluate its medicinally important bioactive molecules.

\section{Conclusions}

Plants have been a prime source of highly effective conventional drugs for the treatment of many forms of cancer. Plants provide active constituents which acts directly against various ailments or indirectly by providing leads for the development of potential novel agents. Large number of herbal species has been used traditionally or as folk medicines against cancer. Many of them have been studied scientifically and proved to be a beneficial anti-cancer agent. In medicine, particularly in the field of cancer, the use of herbs is increasingly enhanced especially with the excessive use of synthetic drugs and awareness of their toxicity, which contributed in oncology, leading to a favorable reconsideration of the medicinal practices made from natural herbs. Despite the divergent bioactivities of the plant medicines against various diseases, active components of most plant extracts have not been elucidated thoroughly, due their complex mixtures. The ability of agents to attach to carrier molecules directed to specific tumors, shows highly cytotoxic natural products to the tumors. A better understanding of the characteristics of tumor cells has recently led to the development of more target oriented treatments, and therefore found to be less toxic. In conclusion, the use of naturally occurring molecules in the treatment of cancer and other disease has greatly contributed to the improvement of the therapeutic efficacy of drugs used today. In this review, the biological activities of different species of the genus Annona of Ethiopia, North East Africa 


\section{International Journal of Science and Research (IJSR) \\ ISSN (Online): 2319-7064 \\ Index Copernicus Value (2013): 6.14 | Impact Factor (2014): 5.611}

with their phytochemical and pharmacological profile are presented but, some species of the genus Annona specially graviola of Ethiopia does not have scientifically proven information regarding their safety profile and biological efficacy. These plants exhibit good characteristic against leading life style diseases. This article provides some basic knowledge of medicinal plant species of the genus Annona of Ethiopia, North East Africa.

\section{Acknowledgement}

The authors which to appreciate the effort of Prof Behailu Etana Disasa of Natural Resource Management, College of Agriculture and Veterinary Medicine, Jimma University, Jimma, Ethiopia and University of Oslo, Faculty of Mathematics and Natural Science, Centre for Ecological and Evolutionary Synthesis (CEES), University of Oslo, Oslo, Norway; Management of Aksum University, Axum, Ethiopia-1010, North East Africa; Lydia Swapna Nandam of Department of Microbiology \& Genetics, Institute of Fundamental Sciences, Massey University, Palmerston North-4474, New Zealand and especially the corresponding author highly grateful to Prof K R S Sambasiva Rao, Prof D Madan Prasad, Dr K Ammani for their constant support and encouragement.

\section{References}

[1] Adarsh Verma, M., Ajay Kumar, P., Kavitha, D and Anurag, K.B (2011). Antidenaturation and antioxidant activities of Annona cherimola in-vitro. International Journal of Pharma and Biosciences, 2(2):1-6.

[2] Araya, H., Sahai, M., Singh, S., Singh, A.K., Yoshida, M., Hara, N and Fujimoto, Y (2002). Phytochem, 61: 999-1004.

[3] Asholkar, L.V., Kakkar, K.K and Chakre, O.J (1992). Glossary of Indian Medicinal plants with active Principle, 72-73. Publication and information Directorate. New Delhi.

[4] Azene Bekele-Tesemma (2007). Useful trees and shrubs of Ethiopia: Identification, Propagation and Management for 17 Agroclimatic Zones, Edited by: Bo Tengnäs, Ensermu Kelbesa, Sebsibe Demissew and Patrick Maundu RELMA in ICRAF Project, World Agroforestry Centre, East Africa Region, Nairobi Kenya, 2007.

[5] Betancur-Galvis, L.A., Saez, J., Granados, H., Salazar, A and Ossa, J.E (1999). Antitumor and antiviral activity of Colombian Medicinal plant extracts., Mem. Inst, 94(4):531-535.

[6] Bode, A.M and Dong, Z (2009). Cancer prevention research-then and now., Nat. Rev. Cancer, 9(7):508-516.

[7] Cochrane, C.B., Nair, P.K., Melnick, S.J., Resek, A.P and Ramachandran, C (2008). Anticancer effects of Annona glabra plant extracts in human leukemia cell lines. Anticancer Res, 28(2A):965-71.

[8] Degli, E.H., Guelli, A., Ratta, M., Cortes, D and Estornell, E (1994). Biochem J, 301: 161-167.

[9] Edwards, S., Tadesse, M., Demissew, S. and Hedberg, I. (eds.) (2000). Flora of Ethiopia and Eritrea, Volume 2, part 1. The National Herbarium, Addis Ababa, Ethiopia and Uppsala, Sweden. Pp. 10 -12.
[10] Fujimoto, Y., Murasaki, C., Shimoda, H., Nishioka, S., Kakinuma, K., Singh, S., Singh, M., Gupta, Y.K and Sahai, M (1994). Chem Pharm Bull, 42: 1175-1184.

[11] Gallardo, T., Argon, R., Tormo, J.R., Blazques, M.A., Zafra Polo, M.C and Cotes, D (1998). Acetogenins from Annona glabra seeds. Phytochemistry, 47: 811-816.

[12] Harikrishna Ramaprasad Saripalli (2004). Antibacterial activity of Croton bonplandianum, Moringa pterigosperma and Physalis minima. M.Phil Thesis, Department of Botany and Microbiology, Faculty of Natural Sciences, ANU Campus College, Acharya Nagarjuna University, Nagarjuna Nagar, Guntur, Andhra Pradesh, India.

[13] Harikrishna Ramaprasad Saripalli (2007). Antimicrobial Spectrum of Bio-active metabolites from Callus Culures of Croton bonplandianum, Moringa pterigosperma, Physalis minima and their chemical studies. Ph.D Thesis, Institute of Biotechnology, RPSC (MU), Patna, India.

[14] Harikrishna Ramaprasad Saripalli (2012). "Antimicrobial studies on conventional \& cultured Plant tissue extracts" by Dr Harikrishna Ramaprasad Saripalli, I ed, ISBN 978-3-8484-9799-7. LAP Lambert Academic Publishing AG \& Co. KG, Heinrich-Böcking-Straße 6-8, 66121 Saarbrücken, Germany.

[15] Jansi Rani, D., Rahini Devi, R and VidyaShri M (2013). International Journal for Science Inventions Today.

[16]Keinan, E. (1997-1998). Antibody-catalyzed organic and organometallic transformations and chemical libraries of Annonaceous acetogenins., The Skaggs Institute for Chemical Biology Scientific Report.

[17] Kim, D.H., Ma E.S., Suk, K.D., Son, J.K., Lee, J.S and Woo, MH (2001). Annomolin and annocherimolin, new cytotoxic annoaceous acetogenins from Annona cherimola seeds. J. Nat. Prod, 64(4):502-506.

[18] Kirtikar, K.R. and Basu, B.D (1968). Indian medicinal plants (vols. I and II). Lalit Mohan Basu, Allhabad, India.

[19] Li C.M., Tan N.H., Zheng H.L., Mu Q., Hao X.L., He Y.N and Zhou J (1999). Phytochemistry, 50: 1047-1052.

[20] Maria Yolanda Rios, Federico Castrejon, Norma Robledo, Ismael Leon, Gabriela Rojas and Victor Navarro (2003). Chemical composition and antimicrobial activity of the essential oils from Annona cherimola. Revista de la Sociedad Quimica de Mexico, 47(2):139-142.

[21] Newmann, D.J and Cragg, G.M (2007). Natural products as sources of new drugs over the last 25 years. J. Nat. Prod, 70(3):461-477.

[22] Nicholas H. Oberlies, Ching-jer Chang, and Jerry L. McLaughlin (1997). Structure-Activity Relationships of Diverse Annonaceous Acetogenins against Multidrug Resistant Human Mammary Adenocarcinoma (MCF7/Adr) Cells, Journal of Medicinal Chemistry, 40 (13), 2102-2106.

[23] Nithya, T.G., Vidhya, V.G., Sangeetha, K and Vimala Prakash (2011). Phytochemical Screening of a Polyherb Vallarai Chooranam. International Journal of Drug Formulation and Research, 2: 294-301.

[24] Oberlies, N.H., Chang, C.J and McLaughlin, J. L (1997). Structure-activity relationships of diverse Annonaceous acetogenins against multidrug resistant human 


\section{International Journal of Science and Research (IJSR) \\ ISSN (Online): 2319-7064 \\ Index Copernicus Value (2013): 6.14 | Impact Factor (2014): 5.611}

mammary adenocarcinoma (MCF-7/Adr) cells. J Med Chem, 40(3): 2102-2106.

[25] Ogunwande, I.A., Ekundayo, O., Olawore, N.O. and Kasali, A. (2006). Essential Oil of Annona reticulata L. leaves from Nigeria. Journal of Essential Oil Research 18 (4): 88-92.

[26] Padmaja, V., Thankamany, V., Hara, N., Fujimoto, Y and Hisham, A (1995). Biological activities of Annona glabra. Etheneopharmacol, 11; 48(1):21-4.

[27] Pardhasaradhi, B.V., V. Madhurima Reddy, Mubarak Ali A., Leela Kumari A., and Ashok Khar (2005). Differential cytotoxic effects of Annona squamosa seed extracts on human tumour cell lines: Role of reactive oxygen species and glutathione. J. Biosci, 30, 237- 244.

[28] Patel, J.D and Kumar, V (2008). Annona squamosa L.: Phytochemical analysis and antimicrobial screening. Journal of Pharmaceutical Research 1: 34-38.

[29] Polterait, O (1997). Antioxidants and free-radical scavengers of natural origin. Current Org. Chem, 1: 41540.

[30] Rajiv Dahiya (2007). Synthesis, characterization and biological evaluation of a glycinerich peptide cherimol acyclopeptide. E. J. Chil. Chem. Soci.52:1224-1229.

[31] Ruppercht, J.K., Chang, C.J., Cassady, J.M and McLaughlin, J.L (1982). Heterocycles, 24:1197-1201.

[32] Sismindari, Hussana, A. and Mubarika, S (1998). Sequencing of DNA Supercoil Double Helix with In Vitro Method from Annona squamosa L. Majalah farmasi indonesia, 9: 4-8.

[33] Suresh, H.M., Shivakumar, B., Hemalatha, K., Heroor, S.S and Hugar, D.S (2011). In vitro anti proliferative activity of Annona reticulata roots on human cancer cell lines. Phcog Res, 3: 9-12.

[34] Wang, L. Q (2002). Annonaceous acetogenins from the leaves of Annona montana, Bioorg. Med.Chem., (3): 561-65.

[35] Xu L., Sun N and Kong J (1992). Zhonqquo Zhong Yao Za Zhi. 17: 295-96. http://www.blackherbals.com/graviola.htm "Graviola (Soursop)". Blackherbals. Retrieved 30 January 2012.

\section{Author Profile}

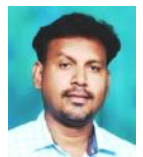

Dr Harikrishna Ramaprasad Saripalli received B.Sc (Biology and Chemistry), M.Sc. (Microbiology), M.Phil (Phytomedicine) from Acharya Nagarjuna University, Ph.D. (Biotechnology) from R P S C (MU), Patna and PDR (Biotechnology) from Dept. of Biotech, AkU in 1995, 1997, 2004, 2007 and 2015, respectively. During Mar ,97- Jul ,97, he stayed in as microbiologist in quality control section at Sangam Diary- Packaging industry; Aug " 97 to Mar ${ }^{\text {"e }} 07$ worked as teacher and researcher at Department of Microbiology and Biotechnology, St. Ann"s College in capacity of Vice Principal, Dean-academics and administration, Head and Staff Secretary; Apr „08-Jun "10 rendered services as a Professor and Head, Department of Pharmaceutical Biotechnology, SIMS College of Pharmacy; Jun "10-Oct "11 worked as an Assistant Professor, Prof in charge for P.G. Exams, Term paper, Mini Project and Ph.D research Program at Department of Biotechnology, K L E F University. He is now with Department of Biotechnology, Aksum University, Axum as an Associate Professor and Chair Person-BtCDDC (Biotechnology Curriculum Design and Development Committee).

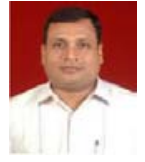

Dr Prasanna Kumar Dixit M.Sc, Ph.D. He is currently the Associate Professor and Head, Post Graduate Department of Zoology, Berhampur University. He has a rich experience in Research, Academics and Administration. Published and presented a good number of research papers, technical papers in reputed journals of National and International repute; seminars and conferences. Was recipient of University Gold Medal and Doctoral Fellowships from CSIR as JRF and SRF; Also member cum patron in several reputed professional and technical associations such as Senate and Academic council of Berhampur University, Member, Board of Studies in Life Sc., Microbiology, Zoology and Environmental Science, Member, DRDC in Zoology, Biotechnology and Pharmacy of Berhampur University; Member, Board of Studies in Life Science, Sambalpur University; Member in editorial board of several journals of Biological importance. 